\title{
DIGITAL TECHNOLOGY FOR EDUCATION VERSUS ENTERTAINMENT: A QUESTIONNAIRE
}

Tatjana R. Marjanović, University of Banja Luka, tatjana.marjanovic@flf.unibl.org

10.31902/fII.27.2019.16

UDK 378:004.738.5

\begin{abstract}
At a time when the world at large has gone entirely digital, we take a closer look at our students and ask whether we can call them techsavvy learners in the true sense of the word. There is some evidence in favour of the assumption that they go about their millennial lives as children of technology: we hardly ever see them without their smartphones; they always seem to have one more text message to send; they routinely take selfies to post them online before our eyes. These examples alone make it all too easy to take their digital literacy for granted. We assume that their preferences, both in and outside the classroom, are in synch with a fully digital state of mind, their study habits included. However, there is no guarantee that our students take an equally digital approach to learning and studying, as doing something for fun and doing something for education are not necessarily two sides of the same coin. In order to shed more light on the issue, a questionnaire has been designed containing five carefully framed questions with no explicit reference to proficiency in the use of modern technology, allowing for a more realistic insight into whether and how digital literacy can become part of one's learning experience. A 100 sample size representative of students majoring in English at the University of Banja Luka, Bosnia and Herzegovina should provide at least some tentative answers about the extent to which they use their digital skills to learn more about the language they are studying.
\end{abstract}

Keywords: digital literacy, students, EFL, questionnaire

\section{Introduction}

The tremendous potential of digital technology is universally proclaimed, just as it is universally acknowledged that success in the digital age requires digital skills. Digital literacy, which is the ability to use computers and other gadgets, search information online, assess it for quality and value, and be able to use it in daily life, is an indispensible toolkit for any successful individual living in the digital world (Internet Society).

As for younger generations, it is not an exaggeration to say that the Internet is at the core of their existence in the world as they know it. Selwyn thus remarks that "online practices have been part of 
young people's lives since birth and, much like oxygen, water, or electricity, are assumed to be a basic condition of modern life" (9).

The Internet is already well incorporated into education in developed countries, and "we can be certain that its worldwide educational significance will continue to increase throughout this decade" (Selwyn 9). It has already superseded libraries as a source for collecting data and doing research, at least in those countries that have access to both the Web and the right databases as a matter of course.

As far as the developing world is concerned, the use of digital technology in education continues to be a widely debated issue marked by a number of controversies, e.g. social, economic, and ideological. One of the questions commonly raised is unequal worldwide access to the Internet as we are reminded of the fact that more than half the world's population has not had first-hand experience using the Internet (Selwyn 9).

Not so long ago, it was possible to access the Internet solely through computers, which many people cannot afford even today. However, the availability of mobile phones has played an important role in expanding Internet access and making it more available to users across the globe (Internet Society).

Despite hopes that Internet access inequality would be counterbalanced by the use of mobile phones, most of the concerns still remain. Firstly, there are features of the Internet that are simply more compatible with a PC, especially in educational settings. Another reason may be the cost of cell phone Internet access. For example, Ramani observes that in India neither smartphones nor tablets have been put to any major use in formal schooling (3). Tablets in particular are more commonly owned by students in urban areas coming from privileged socio-economic backgrounds, but even then the devices are not used primarily for educational purposes (Ramani 6).

These and similar arguments will reverberate strongly in any developing nation facing a host of infrastructural and other problems related to digital technology and its application in education. Therefore, to say that many colleges and universities are making changes to embrace technology by replacing textbooks with tablets, which they provide for their students, is to refer to those educational facilities with enough financial support to follow through such largescale transformative stages in their digital-age makeover.

As a matter of fact, digital equality is not a given even in some of the world's most developed countries. The results of a project coordinated by the U.S. Department of Education point to the existence of digital exclusion, which is understandably more prevalent 
in economically and educationally disadvantaged social groups. In 2015, the two main reasons children lacked Internet access at home were that access was too expensive and that their family did not need it. In addition, differences associated with residence meant that the percentage of students in suburban areas with broadband access at home was higher than that found with students in rural areas, especially those residing in remote places. Within the locale parameter, there were additional gaps observed amongst students of different poverty levels and racial/ethnic groups. For example, in remote rural areas the percentages of students who had no Internet access at home were higher for students in the categories Black and Hispanic than for those in the category White (National Center for Education Statistics 58-83).

The preceding paragraphs make it clear that digital technology and education are invariably discussed as a single entity, just as it is clear that individual practices and degrees of digitalization differ from community to community based on a number of factors, not the least of which are the availability and affordability of infrastructure along with the know-how and readiness of both educational policy makers and practitioners to make formal schooling a fully digital experience for students.

Some societies still cling to the Education 1.0 model, which is used in reference to the first generation of the Web, applying traditional methods of instruction with the teacher taking centre stage and acting as the main disseminator of knowledge. Education 2.0 came into existence at a time when the Web made it possible for users to go from being passive consumers of information to taking an active part in creating content and building knowledge. In other words, this turn-ofthe-century model coincided with tools such as wikis and blog posts, which embrace the principles of active production, collaboration, interaction, and sharing. Education 2.0 is already heavily digitalized, but the principles underlying the extreme and revolutionary model 3.0 (Wikipedia), which is used in reference to socially constructed teaching and learning, envisage a clean breakup with traditional tuition styles. Digital technology reigns supreme in the 3.0 classroom, lectures are replaced by projects and other forms of collaborative learning, while teachers, learners, networks, tools, and resources are all seen as creating a unique entity and doing away with the long-established traditional classroom hierarchies.

It is hard to say whether the educational context of the smallscale project presented in the paper is still best described as the 1.0 model or whether it gravitates more towards Education 2.0 as the time 
passes. What is clear at this point is that all models discussed presuppose some form of digitally supported learning conditioned by a higher of lesser degree of digitalization in education. It seems that it has become virtually impossible to discuss education without digital implications of one kind or another. It is always assumed that it is there - or at least that it should be - whether taking center stage or occupying the proverbial back seats.

On a personal note, I think that I would be very surprised to learn that not all of my students have smartphones. I know that they all have designated e-mail addresses through which school-related matters are bilaterally communicated. I am not sure that each owns a personal computer or a tablet but I do know that they are occasionally required to submit midterm and other papers in electronic form. I have also seen them use power point presentations and draw from numerous Internet sources for their small-scale student research projects.

All this, however, does not mean that they have moved away from the unilateral traditional classroom setup in which the teacher is the sage on the stage, nor that their allegiances lie with collaborative learning tasks, flipped classrooms, and the like. There is no guarantee that they appreciate the connection between digital technology and education or that they have embraced the idea of digitally-enabled education. That is why it is not only their ability to use digital media that informs and intrigues from a teacher's point of view. Rather, what the questionnaire presented in this paper hopes to address is their readiness to make the most of the potential of digital technology in education.

\section{Digital technology and education}

The small-scale research presented in the paper draws data from a questionnaire designed in order to test a proclivity for the use of digital technology on a sample of 100 students majoring in English at the University of Banja Luka, Bosnia and Herzegovina. The questionnaire was instrumental in allowing a better insight into whether or how ingrained digital technology is in the daily lives of the respondents, generally speaking, and especially when utilized for educational purposes.

The design of the questionnaire was inspired by two potentially conflicting assumptions underlying the state of digital literacy in today's world. Much as it is true that lives in the digital age tend to unfold digitally, departures from this general trend are not only due to unequal access to digital media on a global scale but also to a 
tendency to create distinct niches that render digital technology in education secondary to the use of digital media for personal entertainment.

One of the general aims is to compare the findings obtained in this study against what are already established facts elsewhere in the digital world. Given that digitalization, although a global phenomenon, is still a matter of degree, the questionnaire is supposed to provide a few tentative answers and start a discussion about digital awareness and habits, as well as digitally-enabled education, in this corner of the world.

\section{Methods}

\subsection{The questionnaire design}

The questionnaire was designed with the idea not to make the real purpose of the study - the use of digital technology for educational purposes - verbally explicit, so the result was a questionnaire without a single mention of the word digital in it. The questions were framed in such a way as to suggest that we were primarily interested in the respondents' study habits and problemsolving skills, or that we wished to know how they managed their time and resources, broadly speaking. Being less explicit about the real aim of the study was an attempt at capturing and eliciting the students' most instinctive responses: we were working under the assumption that for digital natives (Prensky), a concept which includes both Generation $Y$ and $Z$ (Wikipedia), digital preferences should come almost automatically and override any other.

Also, the technical content found in some of the questions made it clear that the study targeted majors in English rather than any other group of respondents. Admittedly, some information in the questionnaire was rather specialist, but the idea was merely to test whether the respondents would be able to recognize the linguistic cyberspace domain from which the references and their symbols originated.

The questionnaire consisted of a total of five questions, two of which were factual and therefore seeking precise answers, while the three remaining questions were of an open-ended kind, therefore allowing for a range of personal choices, opinions, and experiences to be expressed. Each of the five questions will now be addressed separately and described in more detail.

Question 1 asked the respondents to contextualize and clarify the following references: Bank of English, COCA, and BNC. All the three 
references are the names of some of the largest and most visible English corpora, the two acronyms standing for the Corpus of Contemporary American English (COCA) and the British National Corpus (BNC), respectively. The Bank of English is a collection of English texts mainly British in origin, totalling 650 million running words. Although the corpus is not available for general use, its resounding name was reason enough for including it in the questionnaire. The BNC is another British English text collection, containing 100 million words extracted from mainly written registers of the later part of the $20^{\text {th }}$ century. Originally created by the OUP, it is now available online free of charge thanks to Professor Mark Davies. Davies is also credited for creating the Corpus of Contemporary American English (COCA), which is frequently singled out for its size (e.g. Reppen) as it contains over 500 million words extracted from texts published in the last two decades and belonging to a well-balanced cross-section of registers. Most importantly, this corpus is also accessible online free of charge.

Question 2 asked the students to contextualize and clarify the following symbolic representations: [cc*], s?ng*, and dis*.[vvd]. All three search probes in Question 2 were borrowed directly from COCA (Davies): the question mark refers to a missing letter, the asterisk is a wildcard presenting an item as semantically unrestricted, and the angular brackets specify word class. Accordingly, the first item in Question 2 referenced any of the coordinating conjunctions in English (e.g. and, but, or, etc.); the second item would yield results such as singer, singing, singsong, and so on; and the third one could be any verb in -ed form with the required prefix (e.g. disagreed, discontinued, disarmed, and so forth). This question was certainly the most technical one in the questionnaire and therefore required some specialist knowledge, but the real aim was to see whether the students would establish any links between these cryptic corpora probes and the contents of some of their linguistic courses (e.g. English Morphology or Syntax).

Question 3, which was open-ended rather than factual, aimed at the respondents' preferred course of action in the following circumstances: What do you do if/when you are not sure whether two or more English words go well together (e.g. collocations such as avid readers, a pack of wolves, pluck up courage, etc.)? This question was made part of the questionnaire because it seemed perfectly suited for ascertaining the level of the respondents' digital literacy as well as getting a taste of their study habits. Collocations are one of those aspects of English that can make an L2 speaker's utterances conspicuously unidiomatic. A staggering number of word partnerships 
in English can also put a considerable strain on an L2 learner's memory and cause interference between $\mathrm{L} 1$ and $\mathrm{L} 2$. All these reasons make collocations unavoidable in the process of teaching English as a foreign language from year one onwards. One of the assumptions was that the respondents would resort to online sources more readily for this question than any other in the questionnaire. Another assumption was that collocations dictionaries would feature prominently in their answers. Because this was an open-ended question, all the responses had to be classified and coded prior to their quantification.

Question 4 inquired about what the respondents felt to be the best way to facilitate the process of studying; the couple of examples provided served as a hint that they could choose from an unlimited set of objects and concepts (e.g. coffee, sharp pencils, etc.). This question was in part a distractor, a red herring that was supposed to conceal the real purpose of the study. At the root of the decision not to foreground the idea of tech savvy in the questionnaire was the concern that the respondents would choose 'techy' answers because they felt them to be more politically correct. This strategy also seemed suitable in probing how central their digital awareness appeared to be in their responses when there was no immediate stimulus in the form of actual words on paper evoking the use of digital media. As this was another open-ended question, individual answers were classified, coded, quantified, and tabulated - most typically in the given order.

The same procedure was repeated for Question 5, which asked the respondents to list a few activities that formed part of their daily routine, such as playing chess, writing poems, hanging out with friends, etc. Both the question and the examples provided seemingly had very little to do with measuring the respondents' tech savvy, and yet the question had a dual role: not only did it serve as another distractor masking the real purpose of the questionnaire but also probed which of the two realms, i.e. education or entertainment, was more digitalized in the respondents' answers. Another thought inspired by this question, however tentatively, is whether the respondents spend as much time studying as they are required or may need to, with or without access to digital media. In other words, is the amount of time spent studying largely outweighed by socializing, having fun, or simply going about their daily lives? Although unable to provide any reliable answers in that direction, the question did have the capacity to make one consider the ratio between schoolwork and leisure time in the respondents' lives.

The full form of the questionnaire as administered in the study is presented in the Appendix at the end of the paper. 


\subsection{Data collection}

Data collection was performed in person as it afforded more control of the time parameter: namely, the idea was to restrict the time allowed for writing down responses to about five minutes in order to capture and elicit the respondents' most instinctive reactions. The students who were present in the classroom were first informed that one of their teachers was doing research on their study and time management habits. Besides being made to understand that their cooperation and participation in the study would be greatly appreciated, they were duly reminded that an entirely voluntary and anonymous aspect of the affair meant that, should they feel so inclined, they could opt out without bearing any consequences whatsoever. Indeed, some students availed themselves of the latter opportunity.

A formal classroom setting also offered the administrator the additional advantage of being able to better monitor the process by encouraging the students to be as honest as possible in writing down their answers as well as by preventing them from consulting their classmates or copying their work. Data collection took longer than originally expected: we had to return to the same class as many as three times due to a shortage of respondents, which does not really speak in favour of regular class attendance! However, all the 100 questionnaires were administered three weeks later in April 2016, with each year of study represented by 25 undergraduate students filling in the questionnaire.

The data collected was then organized by means of quantification, codification, or both of these processes combined, depending on whether the question addressed was a factual or an open-ended one.

\subsection{Findings and discussion}

Question 1 was designed to test the degree of the respondents' acquaintance with some of the high-profile English corpora even if they had not had any formal or structured exposure to corpora matters in the classroom. This decision was spurred by the very nature of corpora and their accessibility to language learners.

The advent of corpus linguistics and its effects have spread much further than specialist circles, with electronic corpora becoming ever more accessible to virtually anybody who takes an interest in language matters. Tim Johns, the pioneer of the term "data-driven learning" (DDL), sees the learner as "a language detective" and invents 
the slogan "every student a Sherlock Holmes" (Johns 101). Ever since, corpora have often been credited for allowing incidental learning, which is what happens when a learner stumbles upon a new piece of knowledge by looking at concordance lines (i.e. fragments of text presented in lines on the computer screen with a key word surrounded by more text to the right and left of it). Metaphors such as "the learner as traveller" (Bernardini 22) seem to be quite popular in the context of corpora and autonomous learning. Much like Johns, Bernardini uses the term "discovery learning" and compares corpus-browsing with the exploration of "an unknown land" (166). The ensuing effect often quoted is that of serendipity, i.e. finding something good or useful by chance; Hunston simply describes it as "searching a corpus when the agenda is not too firmly fixed" (171). This is, however, considered to be not only fun but also an entirely meaningful activity since corpora are believed to "encourage reflection" and make a good tool for "the training of inferencing" (Johansson 38). Therefore, although some acquaintance with corpora in the form of classroom tuition can certainly be considered advantageous, there is no reason why language learners should not take the initiative and discover electronic corpora on their own.

The results presented in Table 1 below tested our assumption that most students may have already come across and would accordingly be able to recognize the names of the corpora in Question 1 . Instead, the table shows that only 17 responses out of a total of 300 , as the question included references to three different corpora, could be judged correct. Some of the answers include: the central British bank, the main/official bank in England, the main financial institution in the UK, some dictionary full of English words, vocabulary, the British National Council/Channel/Company, Coca-Cola, and so on. Of the three references, COCA was the most widely recognized one, the other two scoring four hits each, a total of eight.

Question 1: Correct responses to the references provided

\begin{tabular}{ll}
\hline Bank of English & $4 / 100$ \\
COCA & $9 / 100$ \\
BNC & $4 / 100$ \\
\hline
\end{tabular}

Table 1.Correct responses to the references provided

Table 1.1 shows that the two senior years fared a little better than their younger counterparts, but generally the references 
remained mostly unrecognized. Is this to say that if students were not sufficiently encouraged and guided in the exploration of corpora, they would not take advantage of their potential? The results presented in Tables 1 and 1.1 seem to suggest that some learners need to be given more explicit encouragement to start using all the tools and resources available online, including electronic corpora, so they could benefit from them in the long run.

Question 1: Corpora reference recognition

\begin{tabular}{ll}
\hline Year 1 & $1 / 75$ \\
Year 2 & $0 / 75$ \\
Year 3 & $7 / 75$ \\
Year 4 & $9 / 75$ \\
\hline
\end{tabular}

Table 1.1. Corpora reference recognition

One and the same fourth-year student got both of the answers noted in Table 2 right: sing(er) and discovered. Most students decided to skip the entire question, while some of the answers of those who took their chances include: sing, this word, distortion, translation, subtitle, singular, some kind of stop, email stuff, compare and contrast, etc.

It is interesting that none of the senior students was able to recognize the first item in the question, a wildcard for coordinating conjunctions, despite the fact that the year-four English Syntax class was in full swing at the time, focusing precisely on coordinating and subordinating conjunctions. However, it is clear that the [cc*] annotation was significantly more abstract than the other two in Question 2, which was possibly the reason it did not lead to at least an educated guess. Establishing links between different subject areas is a learning trait that working with corpora could help develop and greatly improve in learners precisely because it combines many different aspects of language analysis, e.g. lexical, morphological, syntactic, etc.

Question 2: Correct responses to the annotations provided

\begin{tabular}{ll}
\hline [cc*] & $0 / 100$ \\
s?ng* & $1 / 100$ \\
dis*.[vvd] & $1 / 100$ \\
\hline
\end{tabular}

Table 2.Correct responses to the annotations provided 
As shown in Table 3 below, the four categories derived from answers to Question 3 were presented in order of preference. A caveat is in order here that individual students could suggest several strategies at a time, so the numbers that follow each of the categories in the table signify how many mentions were counted per category.

Question 3: Collocations checking strategies in order of preference

$\begin{array}{ll}\text { Avoidance } & 37 \\ \text { Going online } & 31 \\ \text { Following your instincts } & 24 \\ \text { Using a dictionary } & 23\end{array}$

Table 3. Collocations checking strategies in order of preference

It is somewhat discouraging to see that avoidance is the preferred strategy across the board, as Table 3.1 below shows, with students from all four years of study mentioning it rather consistently in their responses to Question 3. The following wordings all have avoidance as a common denominator: I skip them; I always try to paraphrase; I change the whole sentence; I avoid using them; I try to find a synonym; I use a different collocation, etc.

Question 3: Avoidance as a collocations checking strategy

\begin{tabular}{lr}
\hline Year 1 & 10 \\
Year 2 & 9 \\
Year 3 & 7 \\
Year 4 & 11 \\
\hline
\end{tabular}

Table 3.1. Avoidance as a collocations checking strategy

An ad hoc umbrella term, the least-effort approach could be used in reference to the strategies in Table 3 labelled respectively as avoidance and following your instincts, whether the evasiveness of either kind stems from too much self-confidence (e.g. I believe myself, in the words of one of the respondents) or too little resourcefulness and ambition (e.g. I just do it and hope for the best, as another respondent puts it).

The Internet-themed answers, which also included references to online dictionaries, scored only 31 mentions. One would have expected an online-related answer to this question from almost every 
respondent as it may well be the first impulse, the one idea that crosses one's mind when it comes to collocations.

Question 3: Going online as a collocations checking strategy

\begin{tabular}{lr}
\hline Year 1 & 4 \\
Year 2 & 5 \\
Year 3 & 14 \\
Year 4 & 8 \\
\hline
\end{tabular}

Table 3.2. Going online as a collocations checking strategy

As Table 3.2 suggests, the two senior years seem more open to the idea of checking collocations online, although year four only slightly so. There are only two references to collocations dictionaries on the whole. Some of the answers include: I check their tenses, change one word into a verb, try to rely on Serbian, ask a friend, try to remember whether I've heard them in TV shows and movies, and so on. One student wrote I don't know, and six respondents did not give any answer at all. Another student says s/he goggles (sic) the words, and yet another's response was I search for an answer in some book. Some of the answers are clearly related to insufficiently developed English skills (*studing instead of studying, *concult instead of consult a dictionary, etc). In this respect, it may be worthwhile to investigate whether language proficiency correlates with digital literacy of learners and to what extent.

It has already been remarked that the following-your-instincts category corresponds closely with the avoidance strategy. Taken together, they reach a high score of 61 mentions in the questionnaire responses, some of which underscore reliance on intuition as opposed to an external source of information, e.g. I rely on intuition; I choose the one that sounds better; I am always sure; I follow my instincts; I use it if it sounds good to me, etc. On its own, the following-your-instincts category, as presented in Table 3.3, has received the most mentions by first-year students and the fewest by fourth-year ones; however, both the second and third year figures show a tendency to depart from a trend in which intuition is less relied upon with more experienced students, and vice versa.

Question 3: Following your instincts as a collocations checking strategy

Year 1 8 


\begin{tabular}{ll}
\hline Year 2 & 5 \\
Year 3 & 7 \\
Year 4 & 4 \\
\hline
\end{tabular}

Table 3.3. Following your instincts as a collocations checking strategy

Finally, Table 3.4 gives an idea of how inclined the respondents were to take advantage of what may possibly be the most rudimentary of all strategies to choose from in response to the Question 3 script, i.e. looking it up in a dictionary. The number of mentions ranges from five, for years one and three, to seven, which is attributed to year four; the remaining six mentions are credited to year two. Why there should be relatively few references to this common-or-garden strategy is a difficult question to answer. However counterintuitive it may be, one thought is that some of them still have not developed a habit of looking words up in a dictionary.

Question 3: Using a dictionary as a collocations checking strategy

\begin{tabular}{ll} 
Year 1 & 5 \\
Year 2 & 6 \\
Year 3 & 5 \\
Year 4 & 7 \\
\hline
\end{tabular}

Table 3.4. Using a dictionary as a collocations checking strategy

When asked about their study habits and preferences, the respondents mentioned a variety of different ideas, which were then grouped into one of the four categories: digital, traditional, internal, and environmental. Table 4 gives an overview of the distribution of their answers per category, with each of the figures referring to the number of mentions rather than percentages as individual respondents would typically offer more than one answer to this question.

Question 4: Categories expressing study habits and preferences

\begin{tabular}{lc}
\hline Digital & 4 \\
Traditional & 32 \\
Internal & 54 \\
Environmental & 57 \\
\hline
\end{tabular}


Table 4. Categories expressing study habits and preferences

It is striking how few of the responses in Table 4 are of a digital kind, e.g. the Internet, computer, laptop, etc. It almost appears as if the respondents self-censored heavily in expressing their preferences to the use of digital technology when studying. Why they might feel a need for self-censorship, should the assumption be right in the first place, is an interesting question in itself. Could they be thinking that they are expected to stay away from digital media when studying? Another possibility coming to mind is that digital aids are so common nowadays that they are implied and almost go without saying. Ultimately, much as we find it hard to accept, we cannot dismiss the possibility that some students genuinely do not have digital preferences as part of their study habits. Yet, without a follow-up interview to confirm these suspicions, I believe that any definitive conclusion in that direction would be premature. Table 4.1 below highlights how sparingly digital preferences appear in responses to Question 4.

\begin{tabular}{lc} 
Question 4: Mentions of digital technology for education \\
\hline Year 1 & 0 \\
Year 2 & 1 \\
Year 3 & 2 \\
Year 4 & 1 \\
\hline
\end{tabular}

Table 4.1. Mentions of digital technology for education

Another surprising finding was that of the four mentions of the Internet and/or a laptop in the questionnaire, only one respondent was explicit about using the Internet to get more information when studying. At the same time, the pen-and-paper category, in Table 4 referred to as traditional, still seems to be going strong as many more respondents pledge their loyalty to books, notebooks, pens, pencils, as well as highlighters and colouring markers to help them better organize study materials. Table 4.2 below tentatively points to a trend in which reliance on traditional methods increases with time spent studying at university, although the first two years have evened out their score for this category of Question 4.

Question 4: Traditional preferences mentioned 


\begin{tabular}{lr}
\hline Year 2 & 6 \\
Year 3 & 9 \\
Year 4 & 11 \\
\hline
\end{tabular}

Table 4.2. Traditional preferences mentioned

As can be seen in Table 4 above, the respondents generally expressed the least need for virtual study aids, which stands in sharp contrast with a score of 54 mentions within the category dubbed internal and 57 within the one dubbed environmental. As the mentions were distributed relatively evenly across all four years of study, no separate tabular representations were considered necessary. The category in Table 4 referred to as environmental mentions conditions that are in part ambiental: some students are night owls and seek a quiet place to study, while others prefer to study during the day and do not mind background noises. Another set of conditions encountered in their answers appears to be of a nutritional kind (e.g. coffee, snacks, and so forth). When their responses took a more ethereal turn, mental prerequisites like sleep, concentration, and so on would frequently reappear in the questionnaire. The umbrella term selected for this category (i.e. internal) combines their need for coffee and a focused mind.

Otherwise, the role of technology here coincides with environmental factors like playing music on their laptops. Three students say in no uncertain terms that they see technology as a distraction: no technology in sight, never digital materials, and I need to be away from my laptop were the actual wordings used. Responses such as these make us wonder whether the digital category score in Table 4 was indeed more meaningful than we were initially prepared to admit. Could it be that most respondents simply do not see digital technology as central to their studying although it may well be central to many other non-studying aspects of their lives?

According to Table 5 below, technology for education and technology for entertainment are to be understood as largely separated domains. This is, in fact, the only of the five questions in the questionnaire that puts the use of digital technology at the top of the list before any other category created to accommodate the answers provided by the respondents. That said, it is true that most responses include watching films and TV shows, or listening to music, while only 22 suggestions go beyond that basic package and mention, for example, YouTube videos, computer games, e-books, tablets, Skype, or 
just the good old Internet. These preferences would be more along the lines of using technology for fun in creative and innovative ways: showing their familiarity with e-books or similar digital forms would already make compelling enough a case for reaffirming the students' digital native status.

On the whole, we can conclude that they resort to digital media for entertainment more often than they do for studying, as well as that they mostly access them routinely to watch films and television and listen to music rather than, for instance, taking advantage of a more varied range of digital media or at least some of the extended functions of the ones that they do make use of.

Question 5: Categories expressing extracurricular activities in order of preference

Technology for fun $\quad 64$

Hanging out 57

Sports and leisure 51

Getting creative 41

Table 5.Categories expressing extracurricular activities in order of preference

As for the variety and scope of responses offered by the students, it should be pointed out that a total of 213 mentions of activities grouped into four broad categories as outlined in Table 5 exceeds by dozens any other score in the questionnaire (cf. a total of 147 mentions for Question 4 and that of 115 for Question 3). This might as well be a hint towards what the majority of students taking part in the questionnaire intuitively felt to be a more familiar and indulgent area of life.

Table 5.1 below shows a relatively even distribution of responses across the four years of study, which points to a high degree of consistency when using digital media for purposes other than studying. Neither their age nor their experience as college students seem to have the power to change in any significant manner the view of digital technology as being best suited to one's extracurricular (i.e. leisure) activities.

Question 5: Mentions of digital technology for entertainment Year 1 16 


\begin{tabular}{ll}
\hline Year 2 & 16 \\
Year 3 & 14 \\
Year 4 & 18 \\
\hline
\end{tabular}

Table 5.1. Mentions of digital technology for entertainment

\section{Conclusion}

Judging by the responses analyzed in the questionnaire, it looks as if digital topics may still be somewhat subject to selfcensorship. Otherwise, it would be difficult to explain why digital media are mentioned relatively rarely in responses to all the five questions in the questionnaire. Perhaps the respondents are too wary of the gap between their millennial selves and their pre-millennial teachers, and accordingly think it inappropriate to prioritize digital answers over what they believe to be traditional preferences. Perhaps they do not think they are expected to use the Internet for learning, or that it might even discredit them in the eyes of their teachers. Another possibility is that the respondents were misguided in their answers by the design of the questionnaire, which deliberately avoided explicit references to all things digital in the five questions. Last but not least, could it be that the respondents' digital habits were justly described and represented in their answers? Regardless of which of these possibilities may be true, it is rather worrying that they should still not fully understand that digital technology can be utilized in education to great effect and their teachers' unreserved approval.

The trends uncovered by the questionnaire should be informative to all parties concerned: teachers need to keep working on reinforcing the connection between digital technology and education, while students need to be made aware that it is perfectly acceptable, even desirable, to use digital media even in the most formal of educational settings. In the long run, it may also be useful to compare these results with others and see whether there is a correlation between digital proficiency and learning success, for example.

\section{References:}

Bernardini, Silvia. "Exploring New Directions for Discovery Learning." Teaching and Learning

by Doing Corpus Analysis: Proceedings of the Fourth International Conference on Teaching and Language Corpora, Graz 19-24 July, 2000. Amsterdam: Rodopi, 2002. 165-182. Print. 
Bernardini, Silvia. "Corpora in the Classroom: An Overview and some Reflections on Future Developments." How to Use Corpora in Language Teaching. Ed. John Sinclair. Amsterdam: John Benjamins, 2004. 15-36. Print.

Davies, Mark. The Corpus of Contemporary American English (COCA): 560 million words, 1990-present. Web. 15 July 2018.

"Education 3.0." Wikipedia. Web. 17 July 2018.

Hunston, Susan. Corpora in Applied Linguistics. Cambridge: CUP, 2002. Print.

"Internet Access and Education: Key Considerations for Policy Makers." Internet Society, 2017. Web. 17 Oct. 2018.

Johansson, Stig. "Some Thoughts on Corpora and Second-Language Acquisition." Corpora and Language Teaching. Ed. Karin Aijmer. Amsterdam: John Benjamins, 2010. 33-44. Print.

Johns, Tim. "Contexts: the Background, Development and Trialling of a Concordance-Based CALL Program." Teaching and Language Corpora. Ed. Anne Wichmann. Harlow: Longman, 1997. 100115. Print.

“Millennials." Wikipedia. Web. 17 July 2018.

Prensky, Marc. "Digital Natives, Digital Immigrants." On the Horizon 9.5 (2001): 1-6. Print.

Ramani, Srinivasan. "The Internet and Education in the Developing World - Hopes and

Reality." Smart Learning Environments 2.8 (2015). Web. 18 July 2018.

Reppen, Randy. Using Corpora in the Language Classroom. Cambridge: CUP, 2010. Print.

Selwyn, Neil. "The Internet and Education." Ch@nge: 19 Key Essays on How the Internet

Is Changing Our Lives. Digital Education Research, 2013. Web. 11 Oct. 2018.

U.S. Department of Education. National Center for Education Statistics. Student Access to

Digital Learning Resources Outside of the Classroom. U.S. Department of Education, 2018. Web. 18 July 2018.

\section{УПИТНИК О ДИГИТАЛНИМ ВЈЕШТИНАМА И НАВИКАМА СТУДЕНАТА У УЧЕЊУ НАСУПРОТ ЗАБАВИ}

У ери глобалне дигитализације лако се стиче утисак да се аспекти технолошке културе преносе у великој мјери на готово све сфере живљења. У случају образовног система, учења и 
студирања, то би значило да се свакодневне активности проводе уз значајну технолошку подршку расположивих средстава. Постаје готово немогуће замислити наставу без паметних телефона и апликација, што очекивано наводи на закључак да се и учење одвија на подједнако технолошки начин. Међутим, није нужно да се примјена дигиталне технологије у домену свакодневне комуникације и забаве у истој мјери преноси и на домен учења и студирања. Како би се дошло до објективнијих сазнања о употреби дигиталних вјештина које постају навике у учењу, састављен је упитник са пет пажљиво уобличених питања без експлицитног позивања на дигиталну технологију. Овакав концепт упитника у складу је са тежњом да се покушају избјећи политички коректни одговори испитаника. Истраживање је проведено на Универзитету у Бањој Луци, а испитаници су студенти енглеског језика и књижевности на све четири године додипломског циклуса. Укупан број подијељених упитника износи 100, по 25 на свакој години студија. Анализа одговора би требало да омогући боље разумијевање улоге коју на овим просторима технологија попут рачунарске има у образовању ван учионице. Поставља се и питање дигиталне писмености и спремности студената да поменуте вјештине користе у стицању нових спознаја о језику који студирају.

Кључне ријечи: дигитализација, технологија, упитник, студенти, енглески језик

\section{Appendix}

\section{QUESTIONNAIRE}

You need not write your name, only circle the year of study in which you are enrolled:

$12 \quad 2 \quad 3 \quad 4$

The questionnaire should not take more than 5-10 minutes of your time. Try to answer the questions below as honestly as you can without worrying about what may be the 'right' answer. Even 'I do not know' will be taken as a perfectly legitimate answer.

1 If you can, contextualize and clarify the following references: 

a. Bank of English
b. COCA
c. $\quad \mathrm{BNC}$

2 If you can, contextualize and clarify the following symbolic representations:
a. $\left[\mathrm{cc}^{*}\right]$
b. s?ng*
c. dis*.[vvd]

3 What do you do if/when you are not sure whether two or more English words go well together (e.g. collocations such as avid readers, a pack of wolves, pluck up courage, etc.)?

4 When you sit down to study, what do you need most (e.g. coffee, sunlight, sharp pencils - anything at all) and why? Restrict your answer to one or two items.

5 How do you spend your time when you are not busy studying? Can you name a few activities - however simple - that make part of your daily routine or that you simply enjoy doing (e.g. playing chess, writing poems, hanging out with friends, etc.)?

Thank you for your time! 